\title{
Implementing a Genre Pedagogy to the Teaching of Writing in a University Context in Thailand
}

\author{
Tawatchai Chaisiri \\ University of South Australia \\ tawatchai.chaisiri@postgrads.unisa.edu.au
}

\begin{abstract}
English writing instruction is very difficult, but the task is even greater in EFL contexts. When considering alternative teaching approaches, it is important to note teachers' perceptions and concepts regarding their teaching practices. This paper reports on a study into how writing teachers perceive their current approaches and the consequences of implementing a genrebased approach in one writing classroom. Teacher perception data were generated through a questionnaire and interviews. Action research was employed to improve the teaching approach in the classroom. Data were analysed both quantitatively and qualitatively. Findings reveal that the teachers used a combination of approaches in their teaching and that many aspects of their teaching include the notion of genre. The classroom research led to clear improvements in student writing and to positive attitudes by participants. This paper suggests implications for the teaching of writing in similar EFL contexts.
\end{abstract}

Providing writing instruction in L2 contexts is considered difficult, but as Richards and Renandya (2002) have noted, it can be quite challenging in L1 settings too. However, the level of difficulty increases markedly when conducted in EFL contexts where learners are rarely exposed to English or to the demands of writing English. The problem exists globally. Lin (2003) mentions the difficulty in Singapore where many students still cannot use English effectively for academic or real-life purposes even after completing English courses in secondary school. Similarly, Kim (2006) points out the difficulties which Korean university students face when writing compositions. Difficulties in teaching and learning writing in Thailand have also been reported by researchers such as Foley (2005).

Apart from the well-known "product and process" approach of assisting English learners in developing their writing skills, a recent methodology, known as a genre-based approach, has been proposed as being applicable to the Thai EFL context (Kongpetch, 2006; Walter-Echols, 2009). A genre-based approach has been developed from Systemic Functional Linguistics (SFL) which proposes a model of language comprising the context of situation and the context of culture. This has been developed by Martin (1984) and further refined by others such as Rothery (Callaghan \& Rothery, 1988) and Christie (1999).

This study investigated the feasibility of applying research findings by using a genre-based approach in the context of a Thai university undergraduate English major course. In Phase 1 of this study, writing teachers' perceptions of teaching methodologies in their practices were surveyed to identify perspectives that might have relevance to the introduction of a genre- 
based approach. In Phase 2, an action research study, the effects of implementing a genrebased approach in a writing classroom were examined. These research questions were used to frame the overarching inquiries:

- What are teacher perspectives on teaching English writing in the Thai university context?

- What are the effects of implementing a genre-based approach to the teaching of writing in one English-major classroom?

\section{Literature Review}

SFL genre theory holds that language is operated in two kinds of contexts. The first is the context of culture, or "genre," in which people in the culture share particular social purposes using the language. This varies based on the second kind of context, situational context, in which language use is related to three features: the topic talked or written about (field), the relationship between the speaker and listener or writer and reader (tenor), and the channel of communication—spoken or written (mode) (Gibbons, 2007; Halliday, 1985, 1994; Hyon, 1996). These features are known as register. The systemic perspective "considers language primarily as a resource for making meaning rather than as a set of rules" (Paltridge, 2007, p. 933). The focus of this genre tradition is on the teaching and learning of school genres in primary and secondary school, as well as English as a second language in adult education. For analysis, SFL scholars employ the linguistic features of genres developed by Halliday (1985).

In genre-pedagogy, the notion of scaffolding is embedded in the teaching and learning process. Vygotsky emphasized "interactive collaboration between teacher and student, with the teacher taking an authoritative role to scaffold or support learners as they move towards their potential level of performance" (Hyland, 2003, p. 26). Support can be conceptualised as a situation in which a child can achieve a task supported by caretaker, with the support gradually removed when the child can perform the task independently. Bruner (1978) describes scaffolding as "the steps taken to reduce the degrees of freedom in carrying out some tasks so that the child can concentrate on the different skill she is in the process of acquiring" (p. 19). In classroom interaction, scaffolding is temporary assistance provided by the teacher in helping students carry out tasks or develop an understanding of the subject so that the students are capable of accomplishing the tasks by themselves (Hammond \& Gibbons, 2001).

Employing the genre pedagogy in this study, the focus was on explicit or visible pedagogy (Hyland, 2003). In this regard, the teacher's role is to support students in learning through an awareness of target genres and explicit and conscious language choices. Students are provided with a clear understanding of the purpose of text and language use in regard to both a cultural context (genre) and a situational context (field, tenor, and mode). Students may be encouraged to deconstruct model texts to make sense of the generic structure and linguistic features of the text. Other communicative activities which include Communicative Language Teaching (CLT) (Burns, 2001) may be included to encourage reflection on writing practices exploiting genre pedagogy and to create portfolios of students' genre writing (Paltridge, 2001).

The main process of teaching and learning in the classroom is known as the teaching and learning cycle. It comprises four stages: Building Knowledge of Field, Modelling of Text, Joint Construction of Text, and Independent Construction of Text. In Building Knowledge of Field, students are exposed to discussions or activities that foster students making sense of the situational and cultural context of the genre under study. For Modelling of Text, the focus is on text analysis, which draws students' attention to identifying the purpose and the generic (schematic) structure and language features of texts. In Joint Construction, the teacher and the 
students construct a text together. The teacher is a scribe, writing students' contributions on a board. The teacher may also have to re-word students' sentences to make them genreappropriate. When students are confident enough, they move into Independent Construction, which requires students to write on their own. This approach is further facilitated if the teacher meets with individual class members to help each with the assignment.

The genre principles used in this study include the concept of the relationship of a text to its context, the notion of scaffolding, and explicit instruction of the purpose, generic structure, and language features of a text or genre. These aspects of teaching are implicitly embedded in the teaching and learning cycle highlighted in the teaching and learning activities in the classroom.

\section{Research Methodology}

This study comprised Phase 1, a survey of writing teachers' perceptions of teaching writing using a questionnaire and interviews as research tools, and Phase 2, a genre-based classroom action research aiming to implement and improve the more recent approach in the classroom. The work was conducted in 21 campuses of the Rajamangala Universities of Technology (RMUT).

\section{Participants}

In Phase 1, writing teachers nominated by the English Departments of 21 campuses where English for International Communication (EIC) programs were taught were invited to participate in this research project. Of 105 copies of questionnaires distributed to nominated teachers, 63 $(60 \%)$ were returned for data analysis. For the interview, ten writing teachers on one campus were selected, all having taught English for ten years or more.

In Phase 2, participants included 40 second-year EIC-major students who volunteered to contribute to this study, as well as one writing teacher working collaboratively with the researcher in class. This teacher was both a research subject and a research assistant in that he took the role of observer when the researcher was teaching, conducted one focus group, and engaged in collaborative reflection with the researcher.

\section{Instruments and Procedures}

Data were collected in the second semester of the 2008 Thai academic year. In Phase 1, the questionnaire was developed and trialled with a number of TESOL Research Group members at the University of South Australia (UniSA) before being administered to the respondents. Questionnaires with pre-paid stamped envelopes were mailed to 21 RMUT English Departments across Thailand. Follow-up telephone calls encouraged recipients to return the questionnaire.

For the semi-structured interviews, consent forms were prepared and appointments were made for interviews, which were expected to last about 30 - 60 minutes each. The interviews were transcribed for thematic data analysis; some were translated for data presentation.

Action research tools in Phase 2 comprised classroom observation notes by a non-participant teacher, interview schedules, journals, and artefact collection of student writing (preintervention, post-intervention, and in-class writing). The genre-based writing course was taught over eight weeks, with a two-and-a-half-hour weekly class. The four text types being taught comprised Recount, Instruction/Process, Explanation, and Argument. The students were asked to participate in focus group discussions which took about 10-20 minutes following each class. Initial data analysis was used to improve the teaching on site, following the action 
research spiral (Cohen, Manion, \& Morrison, 2000) where the planning-acting-observing-andreflecting process was employed.

\section{Data Analysis}

For the first part of the questionnaire data, descriptive statistics were used, comprising mean score and standard deviation (SD). For the qualitative data (interviews, journals, and student writing), key concepts/codes were grounded from the data; they constituted theme identification. The prevalent process of thematic analysis comprises the stages of naming, grouping, finding relationships, and displaying results (Freeman, 1998).

\section{Key Findings}

\section{Phase 1: Teachers' Perceptions of the Teaching of Writing}

The questionnaire and interview probed teachers' perceptions of teaching writing in terms of teaching approaches, the role of grammar, process writing, teaching procedures, and assessment (degrees of agreement ranging from 1.00 to $5.00=$ strongly disagree to strongly agree). The teachers generally agreed on particular aspects of the work, but for issues where the mean score was about 2.50, no clear conclusions could be determined.

\section{Table 1}

\section{Teaching Approaches}

\begin{tabular}{|l|c|c|}
\hline \multicolumn{1}{|c|}{ Questionnaire item/statement } & Mean & SD \\
\hline $\begin{array}{l}\text { If student writing is successful no matter what teaching approach } \\
\text { is used, you consider this a success in the teaching of writing }\end{array}$ & 3.81 & 0.85 \\
\hline $\begin{array}{l}\text { You are ready to try any approach which has the potential to } \\
\text { improve student writing }\end{array}$ & 4.38 & 0.60 \\
\hline
\end{tabular}

The questionnaire data (Table 1) show that writing teachers generally agreed that students' success in writing was favourable regardless of the teaching approach used. However they expressed willingness to try any method that might improve student learning. For the interview data, the most common methodology used was a combination of the product and the process approaches.

\section{Table 2}

The Role of Grammar

\begin{tabular}{|l|c|c|}
\hline \multicolumn{1}{|c|}{ Questionnaire item/statement } & Mean & SD \\
\hline Grammar is related to meaning making in context & 4.35 & 0.57 \\
\hline Grammar is linked to ability to communicate in English & 4.00 & 0.89 \\
\hline $\begin{array}{l}\text { The language features of text should be taught explicitly in class } \\
\begin{array}{l}\text { Grammatical errors should be ignored and excluded from } \\
\text { assessment criteria }\end{array}\end{array}$ & 3.70 & 0.77 \\
\hline
\end{tabular}

Table 2 shows that grammar plays an important role in teaching writing. Teachers agreed that grammar is related to meaning making and that the language features of a text or genre should be taught explicitly and included in assessment. Most teachers interviewed reported that their students lacked the linguistic knowledge necessary for writing; they suggested that grammar should be taught-especially in the beginning courses of writing. This aspect of teaching is also in accord with the genre pedagogy. 


\section{Table 3}

Process Writing

\begin{tabular}{|c|c|c|}
\hline Questionnaire item/statement & Mean & SD \\
\hline Students need to understand the process of writing & 4.67 & 0.67 \\
\hline
\end{tabular}

Table 3 shows the process of writing was rated as important for students in learning writing. The understanding of process writing varied from teacher to teacher. The common process of writing from the interview data comprises planning or brainstorming, writing, and revising or editing.

\section{Table 4}

\section{Teaching Content}

\begin{tabular}{|l|c|c|}
\hline \multicolumn{1}{|c|}{ Questionnaire item/statement } & Mean & SD \\
\hline $\begin{array}{l}\text { Students have to understand the purpose of the text they are } \\
\text { writing }\end{array}$ & 4.73 & 0.54 \\
\hline $\begin{array}{l}\text { The structure of text should be discovered by students rather than } \\
\text { taught explicitly }\end{array}$ & 2.70 & 0.79 \\
\hline $\begin{array}{l}\text { Students should analyse model texts to gain an understanding of } \\
\text { how the text is organized }\end{array}$ & 4.08 & 0.60 \\
\hline
\end{tabular}

As opposed to process writing, Table 4 illustrates that teachers agreed that they should have their students analyse model texts even though (as noted in the interviews) they did not use the term analysis, e.g., they had students compare and contrast, and discuss general features of texts. The questionnaire data also show that the teachers endorsed the technique whereby the teacher jointly constructs the text with the whole class before students write individually (Table 5). This practice is also relevant to the genre pedagogy.

\section{Table 5}

\section{Teacher and Students Jointly Writing}

\begin{tabular}{|l|c|c|}
\hline \multicolumn{1}{|c|}{ Questionnaire item/statement } & Mean & SD \\
\hline $\begin{array}{l}\text { The teacher and students should jointly write the text before } \\
\text { students write on their own }\end{array}$ & 3.97 & 0.80 \\
\hline
\end{tabular}

\section{Table 6}

\section{Peer Editing/Feedback and Teacher Feedback}

\begin{tabular}{|l|c|c|}
\hline \multicolumn{1}{|c|}{ Questionnaire item/statement } & Mean & SD \\
\hline Peer editing or feedback is necessary in the teaching process & 4.43 & 0.85 \\
\hline Peer editing is more important than teacher feedback & 2.44 & 1.18 \\
\hline
\end{tabular}

Table 6 records that after students write, peer editing was considered important in the writing process, and this is also true for teacher feedback. However, some teachers reported in the interviews that they were not using peer editing because it was time-consuming, and students sometimes only pretended to do the activity. 


\section{Table 7}

\section{Feedback and Assessment}

\begin{tabular}{|l|c|c|}
\hline \multicolumn{1}{|c|}{ Questionnaire item/statement } & Mean & SD \\
\hline $\begin{array}{l}\text { Teacher feedback should be on the structure and language } \\
\text { features of text rather than on the content }\end{array}$ & 2.65 & 1.05 \\
\hline $\begin{array}{l}\text { Correcting mistakes or errors is an important part of the teaching } \\
\text { process }\end{array}$ & 4.03 & 0.99 \\
\hline $\begin{array}{l}\text { Frequent errors or mistakes have to be identified and addressed } \\
\text { for the whole class }\end{array}$ & 4.35 & 0.80 \\
\hline $\begin{array}{l}\text { Teacher-student conferences are not necessary in the process of } \\
\text { teaching }\end{array}$ & 1.95 & 0.85 \\
\hline $\begin{array}{l}\text { A collection of student writing or portfolio is useful in terms of } \\
\text { writing assessment }\end{array}$ & 4.27 & 0.78 \\
\hline
\end{tabular}

Table 7 shows that the teachers were not sure (and some disagreed) whether teacher feedback should be solely on the generic structure and language features of text rather than on content. In this regard, some teachers favoured focusing on content feedback. However, correcting errors and mistakes was considered important, and teachers agreed frequent errors or mistakes should be addressed in class so that students could learn from them. The teachers did not agree that teacher-student conferences were unnecessary, but this means that teacher-student conferences were considered necessary. For assessment, it was generally agreed that portfolios should be used to evaluate student writing. The interview data suggest that some teachers collected student writing for both formative and summative assessments, for improving students' writing skills and for grading.

In summary, the results showed that although most writing teachers reported employing a combination of teaching approaches, they mainly used examples of texts or model texts, had students analyse model texts, taught grammar or language features of text explicitly, and assessed student learning explicitly. These aspects of teaching are in accordance with the genre pedagogy implemented in the classroom in Phase 2.

\section{Phase 2: Investigating the Teaching of Genre-Based English Writing}

The purposes of this phase were to trial the genre-based approach and to improve teaching in the classroom. Throughout the course, implementing the genre principles resulted in improvement in both student writing and satisfaction levels of the participants. They agreed that a genre-based approach was practical and effective in their classroom settings.

Engaging with the teaching and learning cycle. The co-teacher and the researcher planned to teach a genre-based writing class together. The course syllabus and lesson plans (see Appendix A for a lesson plan example) were developed beforehand at UniSA owing to time restrictions. However, communication via e-mail with the teacher was used for class preparation. When the course description and content were agreed upon, suitable course materials were located and then adapted for use (see Appendix B for a sample model text).

The general steps of teaching in the Building Knowledge of Field stage usually started with greeting the class and reviewing the previous lesson. The teacher then presented model texts for the class to think about what they were going to study. This stage also helped elicit students' background or shared knowledge. After the model texts, the teacher reviewed or taught relevant grammatical features. For Recount writing, the class was reminded of the uses 
of past tense, action verbs, and reported speech; for Argument, the focus was on connectives, conjunctions, and active and passive voices. The students reported that they liked this stage because they needed to learn more about the grammatical points used for particular text types.

After Building Knowledge of Field, Modelling was introduced by the teacher, who asked students to analyse the same kind of text as in the previous stage. They analysed the given text and presented the findings to the whole class. The questions asked for the analysis included:

- What is the purpose of the text?

- Who is the writer?

- Who is the audience?

- What is the generic structure and language feature of the text?

Students sometimes spoke in Thai with peers to analyse the text or present their analyses to the class. The native language was allowed since students needed to converse with peers and the class in more complex detail on particular content; otherwise, their spoken English would impede their ability to carry out the task. At this stage, it was found that students' favourite activities were those entailing group work. The co-teacher expressed a similar observation: "From the interview, they [students] said they liked the teaching and learning process...they had fun and enjoyed the activities" (Interview with the co-teacher, Nov. 19, 2008).

When students comprehended the characteristics of a genre, the class then jointly constructed a text of the same kind. As implemented in the classroom, Joint Construction was undertaken by the teacher acting as a scribe, writing words or phrases contributed by students. At this stage, the students regarded the activity as important because "when we say words which are not quite right, you [the teacher] can change them for us right away. This also makes us want to say anything we like" (Interview with Student 01 (St01), Jan. 19, 2009). However, there were also some complaints that not all students could participate in this activity. As a result, for a later class, this stage of teaching involved the teacher and the class jointly planning and writing the introductory paragraph. Then students were divided into groups and assigned a topic sentence for which to write a paragraph. Writing was presented group by group in sequence of the generic structure. During or after the presentations, the teacher and the class gave comments to improve the assembled text. The whole class then jointly constructed the concluding paragraph. Most students expressed satisfaction with these group work activities.

In the stage of Independent Construction, upon completion of their first drafts, the students performed self- and peer-editing. This was then followed by a teacher-student conference to improve the drafts. However, if the teacher required students to write in class, the teacher had to plan in advance by asking students beforehand to search for information which could be used in the writing exercise. Peer and teacher feedback remained important not only in the form of the immediate feedback, but also for use outside the class. This process is in accordance with the teachers' perception of the importance of peer and teacher feedback as discussed in Phase 1.

In considering the process of peer editing, it is relevant here to refer to the writing of St07 (St07). In the interview, St07 said that she wrote her text based on her understanding of what she had learned in class. She then planned her writing in class on the planning sheet provided, and later she wrote according to her plan. She requested that her friend peer-edit for her; the edited draft is shown in Figure 1. 


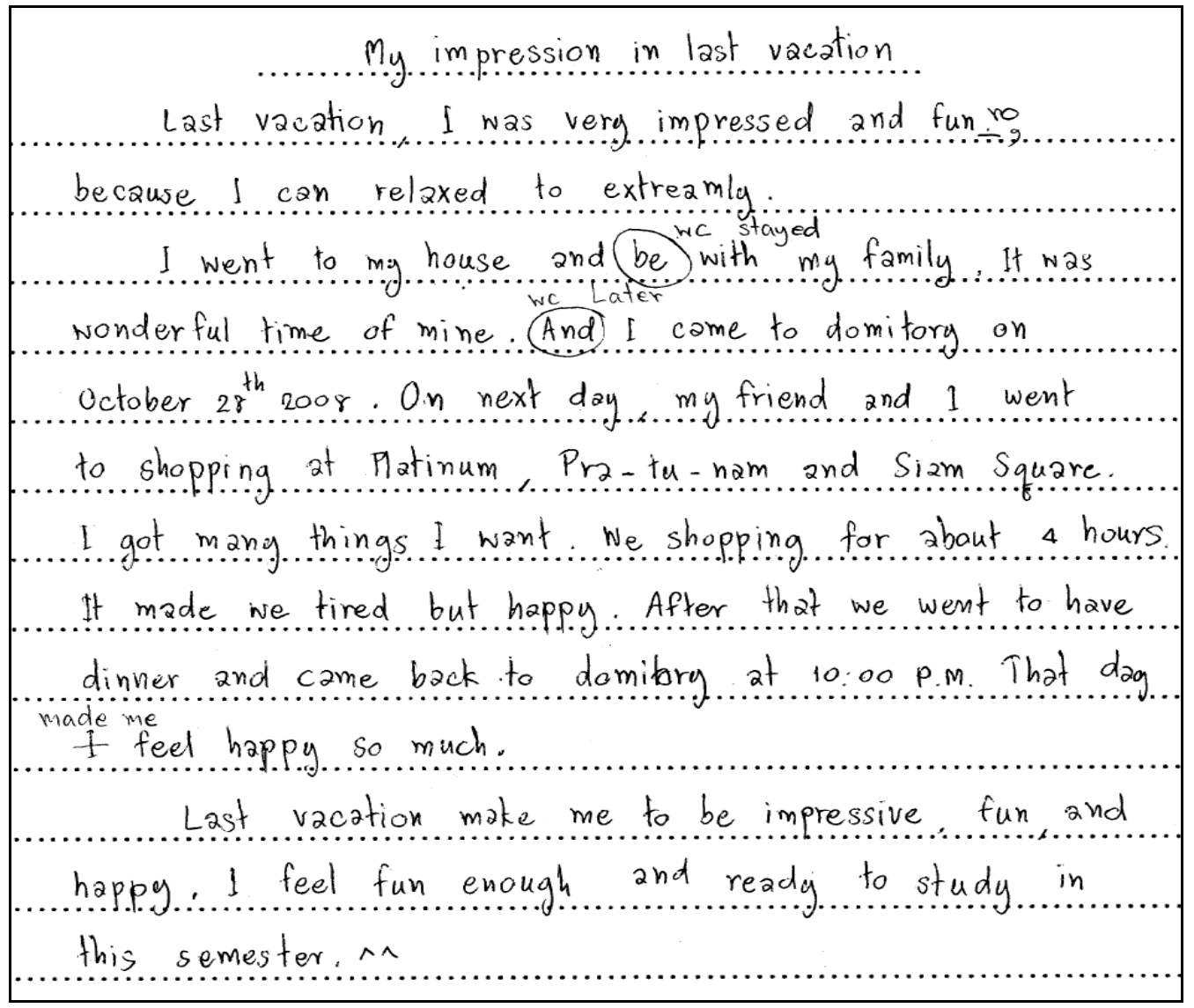

Figure 1. Peer edited draft sample (St07)

Even though her draft contains a few scribbles, St07 asserted that she did both self- and peerediting activities, but she did not write everything in her draft. She looked at the structure of the text first (being guided by the in-class lecture) and made some changes according to what she had learned and what she could recall by reviewing the handouts. Her peer editor then commented on her first paragraph, writing down ro (in line 2; meaning run-on sentence), wC (in line 4; word choice), and made me in line 11 (crossed out l). St07 improved the text in response to the peer comments and then rewrote her second draft for teacher comments. 


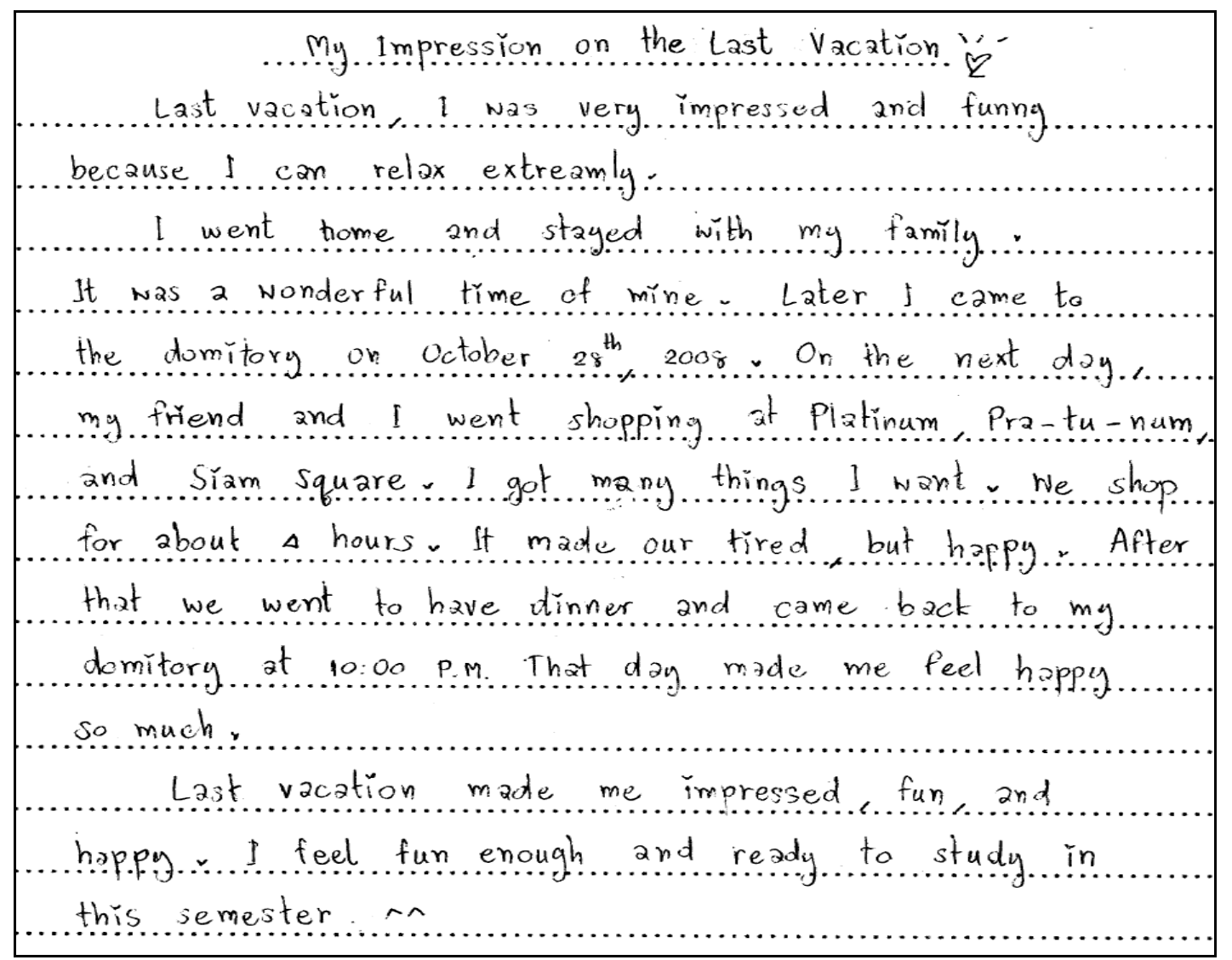

Figure 2. In-class student writing - final draft sample (St07)

Figure 2 is St07's final draft of the in-class Recount writing. The text comprises the generic structure (i.e., title, orientation, sequence of events and reorientation) and some of the language features (e.g., use of past tense and conjunctions) of Recount texts, which had been taught in class. The first paragraph (orientation) should explain what the writer intends to inform the reader by way of general background knowledge. However, in St07's text, the orientation is rather broad because the writer describes activities in general during her vacation. She describes how she went home (she is from a different region), returned to the university, went shopping, had dinner, and retired to her dormitory. She did not describe much about each of the activities. For the re-orientation, she talks about how she felt and in so doing, she restates the introduction.

Particular language features can be noted in St07's text. Most of the verbs are in the past tense, such as was, went, came, and made, while some errors still exist. Some sequence markers can also be noticed, such as later, on the next day, and after that. Additionally, conjunctions and complex sentences can be seen in a few places (e.g., because, line 3).

Considered overall, the process and product orientation of the teaching and learning cycle revealed the effectiveness of the teaching in terms of formulation of in-class student writing. Building Knowledge of Field provided students with fundamental knowledge; Modelling reinforced students' skills in analysing texts; Joint Construction built students' confidence and consolidated their control of genre; and Independent Construction provided students with support from peers and the teacher to enable them to accomplish their individual writing. Overall, this process of teaching satisfied both the teacher and students insofar as it effectively helped students learn to write and improve their writing. 
Comparison of pre- and post-intervention writing. After completing the course, students were requested to write a post-intervention piece to compare it with their pre-intervention writing, both to see how well they had improved their writing competence and to assess the retention of their writing skills. Figure 3 shows St02's pre-intervention writing of a recount.

My Last Vacation
My last vacation was nice. I did internet, download mpa songs and chatting to
my foreigner friends. One day I got free movie ticket for 2 seats. There are tickets
For World Film Festival at siam Paragon. I went to saw movie with my mother.
I was choose movie name "sita sing the bluos". This is animation movie from USA.
Based of this movie comes from Ramayana. I like this movie so much, next I went
to shopping at supermaket. Finally I bought one Favorite book for B2S bookstore.
I didn't do anything much but all that I got is nice vacation.

Figure 3. Pre-intervention writing sample (St02)

St02's text is limited in word length, lacks clarity in terms of structure, and contains errors in the use of verb tense, prepositions, articles, plurals, comma splices, and infinitives. Appraisal of her post-intervention writing (see Figure 4) shows that the text has a clearer structure, contains features of Recount texts, and is more coherent, grammatically correct, and readable. 
Title $\rightarrow$ My.... Impressive....Event.

My. Impressive event is my first . trip . to . Pattay z . with... my family when I was ...7. years old It was my first time that I nent. to the beach. I was so excited to see the beach.

First day y My dad took us . to The Wax museum. I. was atraid.. wax model because I thought the wax models are ghosts we went for lunch . at the .... restaurant near wax museum and bought some fruits ...... .My farily and I arrived hotel in the afternoon My parents took me to the beach near the hate! First time I sow the beach I... felt so exoited and ran into the sea with my older brother..... We took dinner at the restaurant and. I. slept. well . in that night. Next day., .We left hotel in the afternoon and went to the market for sou venir .. I bought some fruits, meat bolls and seafood I felt so happy. in those days

I .can remember this event as well because it was my first time at the sea with my family. I still like to go to the ..... beach nith my family as .. betore.

Figure 4. Post-intervention writing sample (St02)

St02 structured her text with the title, My Impressive Event, followed by three paragraphs labelled orientation, events and reorientation. Use is made of the past tense, albeit inconsistently, and she attempts to use connectives such as First day (in line 5) and Next day (in line 11). Conjunctions and other connectors include because, when, and and. When comparing her pre-intervention with her post-intervention writing, it is clear that significant improvement has been achieved.

St13's Argument writing has characteristics akin to those of St02's Recount writing. The obvious differences between the pre- and post-intervention texts are length and word count, as well as the text structure and language features, as shown in Figures 5 and 6. 


Now Internet is very important in my daily life 1 also
use internet for my studies useing to search important informations
and 1 use to help me with my parttime job to seareh for
new musie they also help alot in trangportations in
sciene and many other things it is like a part of our life now.

Figure 5. Pre-intervention writing sample (St13)

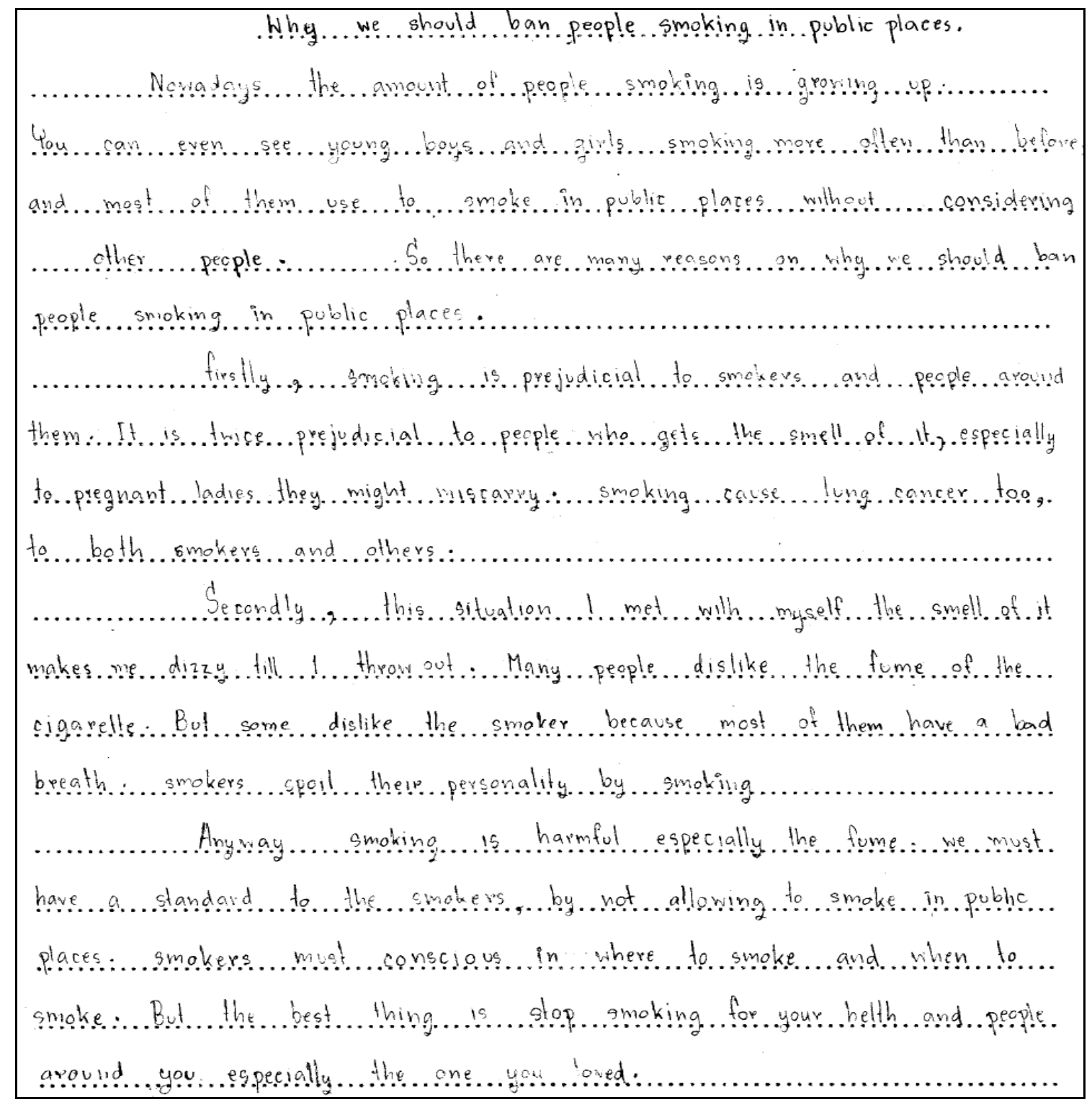

Figure 6. Post-intervention writing sample (St13) 
St13's texts before and after the course are markedly different. In the pre-intervention writing, the student mentions the advantages of the Internet without supporting details, while the postintervention composition includes the title Why we should ban people smoking in public places, and it contains an introduction, a body, and conclusion paragraphs. The use of various language features also indicates improvement in this student's writing.

Implementing a genre-based approach in the writing classroom produced promising results in terms of improvements in student writing, and this reflected both the advantages of the teaching and learning activities in the classroom and the positive attitudes of both the teachers and students toward the teaching approach. In addition, both teacher and students provided suggestions and reflections which contributed to the effectiveness of the approach.

In summary, as illustrated above, both the teacher and the students were satisfied with and had positive attitudes towards the genre-based approach. In addition, the genre pedagogy as identified through the study in Phase 1 was generally in accordance with university English teacher beliefs across the 21 campuses of RMUT.

\section{Implications for EFL Writing Classrooms}

Teachers' perceptions of their teaching practice and the benefits of implementing a genrebased approach in a writing classroom have particular implications for English writing classrooms:

1. Teachers should have a clear purpose for teaching in terms of the particular genre or text type that they expect students to explore. Teachers should draw students' attention to the purpose of text, the intended readership, the generic structure, and the general language features of the text. Other communicative activities can also be incorporated to promote a positive learning environment and student motivation.

2. The teaching and learning cycle can be used as fundamental stages of the teaching and learning process in the classroom. However, the stages are not linear. A particular stage can be applied when needed, e.g., in Building Knowledge of Field, a particular grammatical point featured in a text can be taught (see also Burns, 2009) simultaneously when students start writing their own text and appear in need of grammatical knowledge to accomplish the task.

3. Model texts should be appropriate for students' background knowledge, linguistic ability, and motivation. Much attention should be paid to address students' needs, especially in the first stage, Building Knowledge of Field.

4. Joint Construction should be done with the teacher guiding the students first, if possible, so that students can see how writers (the teacher and class) think and develop the text; students will then gain confidence in producing the same kind of text themselves. Joint Construction can also be carried out by students working in groups.

5. The teacher should encourage students to search for various types of texts of the same genre under study so that students can learn that the genre is dynamic. Creativity can also be developed when students have learned the rudiments of the specific genre.

\section{Conclusion}

In regard to the survey of teachers' perceptions of the teaching of writing and the implementation of a genre-based approach in the classroom, the notion of genre is broadly in line with writing teachers' perceptions and practices. Many aspects of teachers' perceptions are 
congruent with genre pedagogy, such as an understanding of a text having its function in the context, explicit teaching of textual features, the importance of having students analyse model texts to gain control of genre, and the provision of teacher and peer support. These features have been proven to be applicable in the classroom context. In addition, student writing shows evidence of improvement throughout the processes of the teaching and learning cycle in the writing classroom. Teachers' perceptions and understanding of genre pedagogy principles are crucial since teachers frame the overall process of the teaching in their particular classrooms. A closer look into the socio-cultural context where this pedagogical approach is to be implemented and adapted is highly recommended to obtain the maximum benefit from this approach.

\section{Biodata}

Tawatchai Chaisiri has taught English in an EFL context in Thailand for over 15 years. The courses he teaches include fundamental English and English Writing courses. His interest is particularly in teaching writing using genre pedagogy. He is currently an EdD candidate at the University of South Australia.

\section{References}

Bruner, J. (1978). The role of dialogue in language acquisition. In A. Sinclair, R. Jarvella \& W. Levelt (Eds.), The child's conception of language. New York, NY: Springer-Verlag.

Burns, A. (2001). Genre-based approaches to writing and beginning adult ESL learners. In C. N. Candlin \& N. Mercer (Eds.), English language teaching in its social context (pp. 200207). New York, NY: Routledge.

Burns, A. (2009). Grammar and communicative language teaching: why, when and how to teach it? CamTESOL Conference on English Language Teaching: Selected Papers, 5, 915.

Callaghan, M., \& Rothery, J. (1988). Teaching factual writing: A genre based approach. Marrickville, NSW: DSP Literacy Project, Metropolitan East Region.

Christie, F. (1999). Genre theory and ESL teaching: A systemic functional perspective. TESOL Quarterly, 33(4), 759-763.

Cohen, L., Manion, L., \& Morrison, K. (2000). Research methods in education (5th ed.). New York, NY: RoutledgeFalmer.

Foley, J. A. (2005). English . . in Thailand. RELC Journal, 36(2), 223-234. http://dx.doi.org/10.1177/0033688205055578

Freeman, D. (1998). Doing teacher research: From inquiry to understanding. Pacific Grove, CA: Heinle \& Heinle.

Gibbons, P. (2007). Scaffolding language and learning. Teaching ESL students in mainstream classrooms: Language in learning across the curriculum: Readings (2nd ed., pp. 25-37). South Australia: The State of South Australia, Department of Education and Children's Services.

Halliday, M. A. K. (1985). Introduction to functional grammar. London: Arnold.

Halliday, M. A. K. (1994). An introduction to functional grammar (2nd ed.). London: Arnold. Hammond, J., \& Gibbons, P. (2001). What is scaffolding? In J. Hammond (Ed.), Scaffolding: Teaching and learning in language and literacy education (pp. 1-14). Newtown, New South Wales: Primary English Teaching Association 2001.

Hyland, K. (2003). Genre-based pedagogies: A social response to process. Journal of Second Language Writing, 12(1), 17-29. http://dx.doi.org/10.1016/S1060-3743(02)00124-8

Hyon, S. (1996). Genre in three traditions: Implications for ESL. TESOL Quarterly, 30(4), 693722. 
Kim, M. (2006). Genre-based approach to teaching writing. HPU TESL Working Paper Series, 4(2), 33-39.

Kongpetch, S. (2006). Using a genre-based approach to teach writing to Thai students: A case study. Prospect, 21(2), 3-33.

Lin, B. (2003). English in Singapore: An insider's perspective of syllabus renewal through a genre-based approach. RELC Journal, 34(2), 223-246. http://dx.doi.org/10.1177/003368820303400206

Martin, J. R. (1984). Language, register and genre. In F. Christie (Ed.), Language studies: Children writing: Reader (pp. 21-30). Geelong, Victoria: Deakin University Press.

Paltridge, B. (2001). Genre and the language learning classroom. Ann Arbor, MI: University of Michigan Press.

Paltridge, B. (2007). Approaches to genre in ELT. In J. Cummins \& C. Davison (Eds.), International handbook of English language teaching (Vol. 2, pp. 931-943). New York, NY: Springer.

Richards, J. C., \& Renandya, W. A. (2002). Teaching writing. In J. C. Richards \& W. A. Renandya (Eds.), Methodology in language teaching: An anthology of current practice (pp. 303-305). Cambridge, England: Cambridge University Press.

Walter-Echols, E. (2009). Teaching writing by modeling genres through the teaching-learning cycle. CamTESOL Conference on English Language Teaching: Selected Papers, 5, 230238.

Wing Jan, L. (2001). Write ways: Modelling writing forms (2nd ed.). Victoria: Oxford University Press.

\section{Appendix A \\ Recount Lesson Plan}

\section{Class duration}

Two sessions of 2.50 hours each

\section{Objectives}

By the end of the lesson, students will be able to:

1. Tell the purpose of the Recount text type

2. Identify the generic structure of Recount

3. Identify the language features of Recount

4. Write a Recount appropriately

\section{Content}

\section{Definition of Recount}

Recounts are used to reconstruct and describe something that has already happened. They are used to retell experiences and may include the author's or other people's feelings and responses to these experiences. Their cultural purposes are to retell and describe, and inform others of a particular experience in which the author has been involved, although there are some recounts that are imaginative and are not written within the author's experiences.

The information in recount is arranged in a time sequence with appropriate language usage to link the events and to show the passing of time, and may include a personal comment or opinion. Usually a recount quickly establishes (within the introduction) the time, setting and participants in the event to be described. 
There are many different types of recounts, the structures and features of which vary according to the purpose. For example:

- Personal recounts-first- and third-person recounts

- Factual-historical recounts, biographical recounts (including autobiography and memoirs)

- Imaginative recounts—fantasy, adventure, story

Recounts can be in the form of letters, journals, diaries, learning logs, newspaper articles, anecdotes, memoirs, stories, school reports and reflections.

\section{Structure of Recount}

- An orientation that introduces the who, what, when, where of the experience to be described

- Only significant events included

- Series of events often described in the sequence in which they occurred

- Related information grouped in paragraphs

- Paragraphs usually organized in the order that the events occurred

- Topic sentences that include reference to time sequence

- Personal comments, opinions on and/or interpretations of the recounted event or experience

- A reorientation to sum up and conclude the recount

- Appropriate visual text used (maps, timelines, photographs)

\section{Language Features of Recount}

- Specific participants or proper nouns (e.g. Mr Brown, our dog, my school friends, ABC University)

- Personal pronouns (e.g. she, his, her, they, I, my)

- Written in first or third person

- Past tense or action verbs (e.g. went, travelled, stayed)

- Connectives to link events and to indicate time sequence (e.g. then, after that, next, later, a few days later, before, eventually, finally)

- Active and passive voice

- Description to enhance retelling

- Adverbs and groups of words to describe verbs

- Conjunctions to link events and create more complex sentences

- Quoted and reported speech

\section{Activities}

\section{Building Knowledge of Field}

1. Ask students about what they did last week. Have students talk in pairs about their past experiences to their partners. Ask some students to report to the class on what their partners have done during the past week.

2. Elicit students' ideas about where they can find a person's story or recount, and what form of writing it is (e.g. personal letter, email, autobiography, diary, personal essay, etc.)

3. Conclude that each form of writing is called a "genre," and the type of text talking about a person's story is called "Recount." The class discusses the purpose of recount.

4. Hand out a model text (Model Text 1) and a blank piece of paper. Ask students to read the text and then draw a flowchart describing important settings and the sequence of events in the text. 
5. Ask the class to check their flowcharts and discuss the story together.

6. Provide the class with exercises (Exercises 1-2) dealing with grammar points such as past tense, connectives, active and passive voice, conjunctions and reported speech. (These exercises are optional, depending on students' background knowledge of grammar and vocabulary.)

\section{Modelling}

7. Present model texts (Model Texts 1-4) to students.

8. Ask students to compare the texts and figure out the common structure of the texts.

9. Ask students what language features can be drawn from those texts.

10. Conclude with the whole class on the generic structure and language features of Recount texts.

11. Hand out Model Text 5 to students and instruct the class to analyse the text together by trying to answer the following questions:

- What is the text about?

- Who is the speaker of the text?

- Why did the writer write the text?

- How did the writer feel?

- Who is the audience?

- How many paragraphs does the text have?

- What is the main idea of the first paragraph?

- What is the similarity of the first paragraph to the last paragraph?

- What is the main idea in each of the remaining paragraphs?

- What is the first paragraph called?

- What is the last paragraph called?

- What are the rest of the paragraphs called?

- What tense is mostly used in the whole text?

- What other language features can be found in this kind of text?

- What is the overall structure of the text?

12. Provide a few more model texts (Model Texts 6-7) and encourage students to analyse them. Have students work in pairs or groups to try to answer the questions from the previous activity; then have them present the findings to the whole class.

13. Introduce the class to another kind of Recount, Biography by instructing the class to play a "Finding an example" game. Distribute biographical texts (Model Texts 8-9). Ask students to work in pairs and give an example of each of the language features of Recount within five minutes. When the time is up, have the students swap the answer sheets with another pair and check the answers. The pair which has the most correct answers is the winner.

\section{Joint Construction}

14. Jointly compose a piece of Recount together with the class. Elicit ideas from students about imaginary events and the purpose of the writing. Start to write, acting as a scribe or facilitator. Ask students to contribute to the text.

15. While constructing the text, give advice about the generic structure and language features to which students should pay much attention. Explicitly raise grammar points and vocabulary during this class activity. Apply grammar or vocabulary exercises if necessary.

\section{Independent Construction}

16. Ask students to think about what they are going to write on their own. Have students start planning and writing independently. Students should start with outlining what they are 
going to write about according to the generic structure of Recount; that is, orientation, events and re-orientation. Remind students to use various types of the language features of Recount.

17. In the meantime, pay attention to students in case they have any difficulties or questions about their writing. Consult with students individually about their writing.

18. Ask students to revise and edit their first drafts of writing with use of the recount writing self assessment (Assessment Sheet 1). Let students share their writing with their peers and re-edit before writing the second draft.

19. Have a conference with students for them to share problems or concerns; give comments on student writing.

20. Ask students to hand in their work individually and then give feedback based on the Assessment of recount writing (Assessment Sheet 2).

21. Have students improve their writing by using the teacher comments and submit the final draft. Advise students that their completed work be gathered cumulatively throughout the course in the form of a portfolio by students themselves.

\section{Additional Task}

For the next class, students will study the Instruction/Process text type. As homework, assign students to find a topic which is interesting to them. The purpose of this assignment is to prepare students for Instruction/Process writing. Students are supposed to research a topic which suggests a set of processes or instructions for someone to do something. Resources can be of various kinds, such as books, journals, encyclopedias, magazines, and Internet websites. Background knowledge, content, vocabulary and related language about that topic are required in a presentation in the following class.

\section{Materials}

1. Information Sheet 1: Recount

2. Information Sheet 2: Recount planning

3. Grammar and Vocabulary Exercise 1: Reported speech

4. Grammar and Vocabulary Exercise 2: Present/Past participle

5. Model Text 1: A school visit-Tullamore

6. Model Text 2: The Melbourne Zoo

7. Model Text 3: Stitches in my head

8. Model Text 4: The day our duck egg hatched

9. Model Text 5: A visit to our grandparents

10. Model Text 6: The school camp

11. Model Text 7: The hailstorm

12. Model Text 8: Aristotle

13. Model Text 9: John Logie Baird

14. Assessment Sheet 1: The recount writing self assessment

15. Assessment Sheet 2: Assessment of recount writing

\section{Evaluation}

1. Observation on the teaching and learning process

2. Students' presentation on model text analyses

3. Students' participation in class activities

4. Students' contribution and writing

5. Students' portfolios 


\section{Appendix B \\ Model Text 5: A Visit to Our Grandparents}

\section{A visit to our grandparents}

On the weekend, my family visited my grandparents who live on a large farm about 200 kilometres from our place in the city. We visited them because they cannot leave the farm very often to come to the city to see us.

When we arrived on Saturday afternoon, Grandfather made us a cup of Ovaltine and Grandmother gave us a dessert she had just made. It was really delicious. While Mum and Dad sat on the porch and drank their coffee and talked to my grandparents, my brother and I unpacked our bags and spent some time exploring the farm and the rice field.

Just before sunset, Grandfather rounded up the cows and let us feed them a bunch of grass. We watched them swallow their food. They did not eat much of the grass we gave them. Grandfather told us that they all were full since they had eaten a lot of grass in the foothills during the daytime. Then we helped Grandfather get the cows into their pen and watched them take a rest.

After dinner, our grandparents told us about what they used to do when they were our age. They showed us photos of Mum when she was little and before we went to bed, they told us bedtime stories which they used to tell when Mum was a child. We loved the way they told those stories. Our grandparents were really funny when they told the stories.

On Sunday morning we got up early and helped with feeding the cows. After doing that, we helped our grandparents do housework and prepare breakfast. We really enjoyed doing these things because we always help our parents with housework when we are home. Our grandparents were happy with our help.

We left the farm at about 2.30 in the afternoon after we had eaten lunch and helped with the dishes. Before we left, we promised to visit our grandparents during the next school holidays. We promised to stay longer.

During the drive back home, my brother fell asleep in the car because he had done so much on the farm. I told Mum and Dad about all the other things I had done on the farm. Firstly I told them about feeding the calves and then I told them about helping Grandfather to fix the cows' pen. It was worth experiencing and I had never done that before.

On arrival at our house, we woke up my brother. Then we all carried our bags inside and rang our grandparents to let them know that we had arrived home safely. I really enjoyed the trip to the farm. It was a great weekend.

[Adapted from Write Ways: Modelling Writing Forms (Wing Jan, 2001, pp. 99-101)] 